\title{
KAJIAN PENINGKATAN NILAI TAMBAH PRODUK OLAHAN KELAPA DALAM PADA MODEL PERTANIAN BIOINDUTRI DI KABUPATEN MAJENE
}

\section{A Study On Increasing Value-Added of Coconut Products Using Bio-Industrial Agriculture Model In Majene}

\author{
Ketut Indrayana, Hesti Rahasia, Muh. Rikcy, dan Chicilia Iriyani Rayo \\ Balai Pengkajian Teknologi Pertanian Sulawesi Barat \\ Jl. Abdul Malik Pattana Endeng Mamuju, Sulbar) \\ e-mail: ketutindrayanastp@gmail.com
}

Received: 14 Agustus 2020; Accepted: 26 September 2020; Published: 25 Desember 2020

\begin{abstract}
ABSTRAK
Konsep pertanian bioindustri tanpa limbah sebagai salah satu strategi untuk peningkatan nilai tambah dan daya saing serta kesejahteraan petani. Konsep ini, menuntut setiap lini produk mempunyai nilai jual, sehingga penggunan sumber daya menjadi efisien dan dapat menekan biaya produksi. Kegiatan ini dilaksanakan dengan pendekatan kawasan administrasi pemerintahan dalam suatu model bioindustri terpadu yang terbentuk secara partisipatif oleh seluruh komponen masyarakat/lembaga dalam satu desa yang terlibat dalam bioindustri di desa tersebut. Komoditas utama yang ditangani yaitu kelapa dalam. Komoditas lain yang berpotensi meningkatkan nilai tambah dan pendapatan masyarakat secara nyata di masyarakat juga ikut dikembangkan. Hasil kajian ini menunjukan Jumlah kelompok tani yang terlibat dalam kegiatan sebanyak 3 (tiga) kelompok dengan jumlah anggota petani sebanyak 75 orang. Tingkat pendidikan rata-rata dari SD - S1 dengan umur rata-rata 41,63 tahu. Lahan kelapa anggota kelompok yang termasuk dalam kegiatan bioindustri seluas 35,25 ha dengan ratarata kepemilikan 1,33 ha setiap anggota, Pengelolaan Kelapa dalam oleh anggota kelompok tani telah memproduksi atau menghasilkan kopra sebesar $43.234 \mathrm{~kg}$ dengan tingkat nilai penerimaan sebesar Rp. 259.404.000,-, Minyak Kelapa sebesar 10.795 liter dengan tingkat nilai penerimaan sebesar Rp. 161.925.000 dan pengeolahan arang tempurung sebesar $11.326 \mathrm{~kg}$ dengan nilai penerimaan Rp. 45.304.000,-, Nilai penerimaan kotor anggota kelompok tani bioindustri pada tahun 2019 sebesar Rp. 466.633.000- dengan ratarata penerimaan setiap kelompok sebesar Rp. 155.544.333,-, Masih diperlukan peningkatan dan penguatan kinerja kelompok khususnya terhadap peningkatan kinerja anggota, pemanfaatan kelompok tani (gapoktan) sebagai pusat perencanaan dan pelaksanaan kerja anggota.
\end{abstract}

Kata Kunci : Nilai tambah, olahan kelapa, bioindustri

\begin{abstract}
The concept of bio-industrial agriculture without waste is one of the strategies for increasing the added-value product, competitiveness, and welfare of farmers. This concept requires each product to have a sale value so that the use of resources becomes efficient and can reduce production costs. This study was conducted using the approach of the government administration area in an integrated bio-industrial model that is established by the participation from all components of the community including all institutions or organizations in the village. The main commodity studied wasKelapa Dalam (the dalam coconut). Other commodities that have the potential to significantly increase the added value and income of the local community were also being
\end{abstract}

Diterbitkan Oleh, 109

Unit Penelitian dan Pengabdian Masyarakat, Politeknik Pembangunan Pertanian Gowa

http://ejournal.polbangtan-gowa.ac.id 
developed. The results indicated that the number of farmer groups involved in the activities was 3 groups in which the total of the farmer is 75. The average level of education of those farmers was from elementary school to undergraduate and the average age was 41.63 years old. The total of coconut area used for bio-industry activities covered an area of 35.25 ha in which the average of ownership was 1.33 ha per farmer. Since processing dalam coconut, farmers had produced 43,234 $\mathrm{kg}$ of copra with an income of 259,404,000 IDR, 10.795 liters of coconut oil with an income of 161,925,000 IDR, 11,326 kg of coconut shell charcoal with an income of 45,304,000 IDR. The gross receipts of farmers in managing bio-industry in 2019 amounted to 466,633,000 IDR with an average income of 155,544,333 IDR for each farmer groups. The increase and reinforcement for the performance of the farmer group are still needed, especially to increase the performance of farmer group members, the use of farmer groups as a planning center, and the execution of farmer works.

\section{Keywords: Value added, coconut product, bio-industry}

\section{PENDAHULUAN}

Sistem pertanian-bioindustri berkelanjutan selain memungkinkan pengembangan konsep zero waste management, juga pengembangan konsep pertanian berkelanjutan dengan mengintegrasikan aspek lingkungan dengan sosial ekonomi masyarakat pertanian untuk mempertahankan ekosistem alami lahan pertanian yang sehat, melestarikan kualitas lingkungan, dan melestarikan sumber daya alam. Pertanian berkelanjutan harus dapat memenuhi kriteria keuntungan ekonomi, keuntungan sosial, dan konservasi lingkungan secara berkelanjutan pula. Pertanian berkelanjutan juga merupakan tulang punggung bagi terwujudnya ketahanan dan kedaulatan pangan. Sistem pertanian-bioindustri berkelanjutan meliputi: 1) Usaha pertanian berbasis ekonomi intensif (diversifikasi spasial dan temporal, integrasi tanaman-ternak-ikan), 2) pengolahan seluruh hasil pertanian dalam konsep biomassa-biorefinery, 3) Integrasi usaha pertanian-biodigester-biorefinery (Pantjar Simatupang, 2014).

Kementerian Pertanian telah menyusun Konsep Strategi Induk Pembangunan Pertanian (SIPP) 2015-2045: Pertanian-Bioindustri Berkelanjutan Solusi Pembangunan Indonesia Masa Depan. Konsep ini dapat dipandang sebagai awal pencanangan pengembangan bioekonomi berbasis pertanian, landasan strategis dalam pembangunan pertanian jangka panjang, dan mainstreaming perspektif bioekonomi di Indonesia. Implementasi konsep bioekonomi melalui pengembangan Sistem PertanianBioindustri Berkelanjutan secara luas namun bertahap.
Konsep pertanian bioindustri tanpa limbah sebagai salah satu strategi untuk peningkatan nilai tambah dan daya saing serta kesejahteraan petani. Konsep ini, menuntut setiap lini produk mempunyai nilai jual, sehingga penggunan sumber daya menjadi efisien dan dapat menekan biaya produksi (Suswono, 2014).

Kelapa (Cocos nucifera L) memiliki peran strategis bagi masyarakat Indonesia, bahkan termasuk komoditas sosial, mengingat produknya merupakan salah satu dari sembilan bahan pokok masyarakat. Peran strategis itu terlihat dari total luas perkebunan kelapa di Indonesia yang mencapai 3.712 juta hektar (31.4\%) dan merupakan luas areal perkebunan kelapa terbesar didunia. Produksi kelapa di Indonesia menempati urutan kedua didunia yakni sebesar 12.915 milyar butir (24.4\% produksi dunia) (Alamsyah, A. N, 2005). Namun permasalahan dari komoditas tersebut antara lain produk yang dihasilkan terbatas pada bentuk produk primer sehingga tidak kompetitif.

Di Sulawesi Barat, Kelapa dalam termasuk salah satu komoditas perkebunan yang sangat prospektif dan potensial untuk pengembangan bioindustri berkelanjutan, karena memiliki peranan yang sangat penting dalam menumbuhkan perekonomian daerah. Ini terlihat dari luas areal pertanaman kelapa dalam di Provinsi Sulawesi Barat yaitu 42.947 hektar dengan total produksi terus mengalami peningkatan dari tahun $2017 \mathrm{ke}$ 2018 yakni dari 36.469 ton naik menjadi 36.644 ton (BPS Sulawesi Barat, 2019). Produk yang dihasilkan oleh petani kelapa dalam di Sulawesi Barat berupa kelapa butiran, kopra dan minyak goreng yang diolah secara tradisional, sedangkan

Diterbitkan Oleh, 
limbah berupa tempurung, sabut, dan air kelapa belum dimanfaatkan secara optimal (Dinas Perkebunan dan Kehutanan provinsi Sulawesi Barat, 2018). Struktur industri kelapa tersebut menyebabkan nilai tambah yang diperoleh dari proses pengolahan kelapa tidak maksimal dan tidak memberi peluang petani ikut menikmati nilai tambah yang tercipta dalam proses pengolahan hasil kelapa. Disamping itu kendala utama yang dihadapi petani adalah rendahnya harga kelapa butiran, serta keterbatasan modal. Produk olahan kelapa seperti kopra dan minyak goreng kualitasnya masih sangat rendah. Hal ini disebabkan penguasaan teknologi pengolahan hasil masih tradisional, dan kurang memperhatikan faktor sanitasi. Disamping itu produk olahan kelapa belum dilakukan secara komersial dan belum memenuhi standar mutu yang dikehendaki pasar.

Untuk meningkatkan mutu/kualitas hasil dan nilai tambah produk olahan kelapa dalam perlu dilakukan berbagai terobosan untuk mendorong berkembangnya suatu struktur bio-industri yang kuat mulai dari hulu hingga hilir dalam kerangka agribisnis berbasis kelapa. Terobosan inovasi diperlukan baik dari aspek teknologi, sosial ekonomi (kelembagaan dan kebijakan) dalam mengembangkan industri kelapa dalam dari hulu sampai hilir. Teknologi tersebut sudah banyak dihasilkan oleh Badan Litbang Pertanian.

Berdasarkan beberapa uraian permasalahan diatas maka perlu dilakukan suatu terobosan untuk mengintegrasikan semua permasalahan dan potensi usahatani kelapa dalam serta mengoptimalkan pemanfaatan semua sumberdaya yang tersedia untuk meningkatkan produktivitas dan mutu buah kelapa dalam dan produk turunannya, pendapatan petani serta mengelola usahatani ramah lingkungan melalui Pengembangan Model Pertanian Bioindustri Kelapa Dalam di Sulawesi Barat.

\section{MATERI DAN METODE}

\section{Waktu dan Tempat}

Kajian peningkatan nilai tambah produk olahan kelapa dalam pada model pertanian bioindutri di kabupaten majene dilaksanakan di Desa Lombong Timur, Kecamatan Malunda,
Kabupaten Majene. Dengan melibatkan beberapa kelompok tani dari januari-desember 2019

\section{Pendekatan}

Kegiatan ini dilaksanakan dengan pendekatan kawasan administrasi pemerintahan dalam suatu model bioindustri terpadu yang terbentuk secara partisipatif oleh seluruh komponen masyarakat/lembaga dalam satu desa yang terlibat dalam bioindustri di desa tersebut. Komoditas utama yang ditangani yaitu kelapa dalam. Komoditas lain yang berpotensi meningkatkan pendapatan masyarakat secara nyata di masyarakat juga ikut dikembangkan.

\section{Bahan dan Alat}

Bahan dan alat pendukung yang diperlukan dalam pelaksanaan kegiatan in9lain tanaman kelapa dalam dan bahan-bahan lainnya. Alat/mesin pemeras santan kelapa, wajan, saringan, panci, mesin pemarut kelapa, kemasan botol/jirgen, sendok pengaduk, tungku/kompor, baskom, ember, dispenser plastik, karung, cergen, gerobak, parang, gunting pangkas, plastik kemasan, Alat pembuat Arang tempurung danalat tulis dan sebagainya.

\section{Tahapan Pelaksanaan Kegiatan}

\section{Pendampingan penerapan teknologi dan kelembagaan}

Implementasi teknologi inovasi pertanian pada kegiatan bioindustri pada sentra produksi kelapa dalam Teknologi yang akan diterapkan pada tanaman kelapa dalam adalah Penanganan pascapanen dan pengolahan kelapa dalam terdiri dari Pembuatan Minyak kelapa, Pembuatan Kopra, Pembuatan Arang Tempurung Beberapa aspek yang terkait dengan kegiatan bioindustri dan produknya seperti tersaji pada Gambar 1.

Kelembagaan pembangunan pertanianan meliputi kelembagaan petani, kelembagaan keuangan, penyuluhan, pemasaran, dan informasi. Kelembagaan yang menentukan keberhasilan pertanian bioindustri kelapa dalam di Sulawesi Barat adalah sebagai berikut :

1. Kelompok Tani: Pembentukan dan atau penguatan kelompok tani, Pembinaan kerjasama antar kelompok tani, Penumbuhan

Diterbitkan Oleh, 
gabungan kelompok tani menjadi kelompok usaha komersial

2. Klinik bioindustri; Pembentukan dan penguatan klinik bioindustri
3. Pemasaran; Kelompok tani, pedagang, eksportir dan atau industri pengolahan

4. Penyuluhan: Penguatan penyuluhan

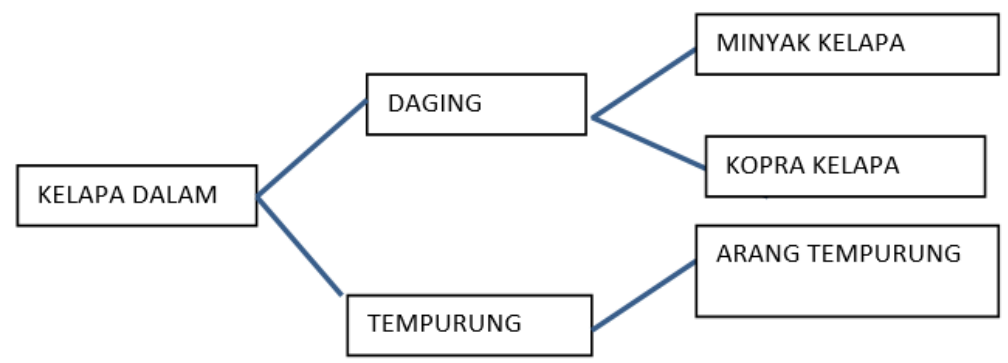

Gambar 1. Pembuatan arang tempurung dan aspek yang terkait dengan kegiatan bioindustri serta produknya

\section{Pelatihan}

Berbagai upaya peningkatan dan penguatan akses petani terhadap sarana dan teknologi salah satunya adalah melalui pelatihan. Pelatihan petani dilakukan di lokasi pendampingan yang melibatkan langsung petani (petani kelapa dalam-ternak sapi) dan narasumber (peneliti, penyuluh dari BPTP/BPTP Sulbar, BALITKA dan instansi yang terkait). Pelatihan yang akan dilaksanakan antara lain : 1) Pelatihan pembuatan minyak kelapa; Pelatihan pengolahan Kopra kelapa; 3) pelatihan pengolahan Budidaya Kelapa, Pelatihan Pemeliharan ternak sapi dan pengolahan pupuk organik padat dan cair.

\section{Jaringan kerjasama}

Jaringan kerjasama terbagi dalam 2 kategori yaitu jaringan kerjasama internal dan eksternal. Jaringan kerjasama internal diarahkan untuk mewujudkan kerjasama sinergis antara elemen-elemen yang ada dalam lingkup Badan Litbang Pertanian yang membentuk laboratorium bioindustri. Jaringan kerjasama eksternal diarahkan untuk mewujudkan kerjasama sinergis antara jaringan Badan Litbang Pertanian dengan pihak luar yang terlibat dalam sistem bioindustri (Pemda, tokoh masyarakat, swasta, LSM, dan masyarakat setempat).

Dalam mewujudkan dan mengembangkan jaringan kerjasama internal dan eksternal perlu dilakukan kegiatan yang bersifat menunjang kegiatan antara lain :
1. Rapat Koordinasi dengan PEMDA, Dinas terkait (Disbun, Disnak, Perbankan)

2. Pertemuan konsultatif dengan Puslit, Balit, PEMDA, LSM, swasta

\section{HASIL DAN PEMBAHASAN}

\section{Potret Kelapa Dalam Nasional dan Provinsi Sulawesi Barat}

Tanaman kelapa merupakan salah satu aset bangsa Indonesia, karena kelapa mempunyai peranan sosial, budaya dan ekonomi. Selain itu tanaman kelapa juga merupakan salah satu tanaman yang seluruh bagiannya dapat dimanfaatkan. Tanaman kelapa tersebar di seluruh Indenesia dengan pulau yang terluas adalah Pulau Sumatera (34,5\%), kemudian diikuti Pulau Jawa (23,2\%), Sulawesi (19,6\%), Bali, NTB dan NTT (8\%), Kalimantan 7,2\%, Maluku dan Papua (7,5\%). Salah satu jenis kelapa yang diusahakan oleh petani adalah kelapa dalam. Perkembangan luas areal, produksi dan produktivitas kelapa dalam kurun waktu antara tahun 2013 sampai tahun 2018 mengalami pertumbuhan yang kurang bagus. Dalam masa 6 tahun tersebut pertumbuhan kelapa mengalami penurunan rata-rata 1,17 persen pertahun. Hal yang sama juga terjadi pada produksi yang mengalami penurunan rata-rata 1,55 persen pertahun. Sementara produktivitas perhektar kelapa dalam tidak pernah sampai 1 ton perhektar. Menurut Budi. S (2016) rendahnya produktivitas kelapa dalam disebabkan oleh: keragaman genetik kelapa masih tinggi, tanaman

Diterbitkan Oleh, 
kelapa dalam kebanyakan sudah tua, penebangan pohon kelapa dalam untuk bahan bangunan dan terjadinya alih fungsi pemanfaatan lahan untuk pemukiman.

Kalau dilihat dari segi kepemilikan kelapa dalam paling banyak dimiliki dan diusahakan oleh petani rakyat. Pada tahun 2018 dari total luas areal kelapa dalam 3.444.349 ha, 3.421.018 ha atau 99.32 persen dimiliki oleh rakyat dan sisanya 0,56 persen (19.392 ha) dimiliki oleh swasta dan
0,11 persen (3,939 ha) dimiliki oleh negara (Tabel 1). Kepemilikan lahan kelapa dalam baik di tingkat rakyat, swasta maupun negara mengalami penurunan selama 6 tahun terakhir. Pada tahun 2013 luas areal kelapa dalam milik rakyat 3.632.483 ha dan turun sebanyak 210.465 ha. Dalam masa yang sama luas areal kelapa dalam yang dikelola swasta turun seluas 623 ha dan luas areal kelapa dalam yang dikelola swasta negara turun seluas 354 ha.

Tabel 1. Perkembangan luas areal, produksi dan produktivitas kelapa dalam

\begin{tabular}{lrrrrrrr}
\hline \multicolumn{1}{c}{ Kepemilikan } & \multicolumn{1}{c}{2013} & 2014 & 2015 & 2016 & 2017 & 2018 & Pertumbuhan \\
\hline Luas areal (Ha) & 3655791 & 3674966 & 3546907 & 3526282 & 351671 & 344434 & $(-1,17)$ \\
Rakyat & 3631483 & 3649928 & 3523020 & 3502792 & 349371 & 342101 & $(-1,18)$ \\
Negara & 4293 & 4622 & 4079 & 3972 & 3887 & 3939 & $(-1,50)$ \\
Swasta & 20015 & 20416 & 19808 & 19518 & 19117 & 19392 & $(-0,61)$ \\
Produksi (Ton) & 3064875 & 3065608 & 2951401 & 2931811 & 292641 & 283380 & $(-1,54)$ \\
Rakyat & 3048650 & 3050596 & 2934471 & 2915038 & 290997 & 281720 & $(-1,55)$ \\
Negara & 3107 & 1858 & 2927 & 2896 & 2862 & 2725 & 2,06 \\
Swasta & 13118 & 13154 & 14003 & 13877 & 13578 & 13883 & 1,18 \\
Produktivitas (Ton/Ha) & 0,84 & 0,83 & 0,83 & 0,83 & 0,84 & 0,82 & $-0,47$ \\
Rakyat & 0,84 & 0,84 & 0,83 & 0,83 & 0,83 & 0,82 & $-0,48$ \\
Negara & 0,72 & 0,4 & 0,72 & 0,73 & 0,74 & 0,69 & 6,31 \\
Swasta & 0,66 & 0,64 & 0,71 & 0,71 & 0,71 & 0,72 & 1,86 \\
\hline
\end{tabular}

Sumber : Direktorat Jenderal Perkebunan

Tabel 2. Perkembangan luas panen, produksi dan produktivitas kelapa dalam menurut Kabupaten di Provinsi Sulawesi Barat

\begin{tabular}{cccccccccccccccc}
\hline \multirow{2}{*}{ Tahun } & \multicolumn{3}{c}{ Majene } & \multicolumn{4}{c}{ Polewali Mandar } & \multicolumn{3}{c}{ Mamasa } & \multicolumn{4}{c}{ Mamuju } & \multicolumn{3}{c}{ Mamuju Utara } \\
\hline 2014 & 9.11 & 9.12 & 1,00 & 22.2 & 19.50 & 0,88 & 7 & 1 & 0,22 & 737 & 3.17 & 0,4 & 1072 & 893 & 0,83 \\
2015 & 9.12 & 10.3 & 1,13 & 20.3 & 18.4 & 0,91 & 147 & 2 & 0,14 & 7.37 & 4.23 & 0,5 & 9404 & 447 & 0,48 \\
2016 & 9.13 & 10.3 & 1,13 & 20.3 & 18.4 & 0,91 & 147 & 5 & 0,40 & 7.37 & 5.36 & 0,7 & 1055 & 947 & 0,90 \\
2017 & 6.76 & 7.10 & 1,05 & 15.6 & 18.33 & 1,17 & 2 & 6 & 0,00 & 4.73 & 4.73 & 1,0 & 6953 & 851 & 1,22 \\
2018 & 8.51 & 6.84 & 0,80 & 21.8 & 17.68 & 0,81 & 131 & 8 & 0,67 & 592 & 5352 & 0,9 & 5346 & 614 & 1,15 \\
\hline P & 0,0 & $-5,4$ & $-4,5$ & 1,9 & $-2,4$ & 0,3 & 114 & 6 & 52 & $-2,7$ & 15,3 & 21, & - & 6,0 & 18,8 \\
\hline
\end{tabular}

Sumber : Dinas Perkebunan Sulawesi Barat. Ket : $1=$ luas panen (ha) $; 2=$ produksi (ton) $; 3$ produktivitas (ton/ha)

Provinsi Sulawesi Barat merupakan salah satu provinsi sentra penghasil kelapa dalam di Pulau Sulawesi. Kondisi perkembangan luas areal dan produksi kelapa dalam mengikuti perkembagan luas areal dan produksi kelapa dalam nasional. Dimana dalam masa lima tahun terakhir (2014-2018) luas areal kelapa dalam mengalami penurunan dari 49.587 ha pada tahun 2014 menjadi 41.738 ha pada tahun 2014. Hal yang sama juga terjadi pada produksi yaitu mengalami penurunan dari 40.755

Diterbitkan Oleh, 
ton pada tahun 2010 menjadi 36.120 ton pada tahun 2018. Kalau dilihat perkabupaten hanya Kabupaten Mamasa yang mengalami penambahan areal luas panen dari 76 ha pada tahun 2014 menjadi 131 ha pada tahun 2018 (Tabel 2).

\section{Karakteristik Desa Lombong Timur}

Desa Lombong Timur kecamatan Malunda, Kabupaten Majene merupakan desa pemekaran dari desa Lombong pada tahun 2010, dihuni oleh sekitar $250 \mathrm{KK}$ mempunyai mata pencaharian utama sebagai petani kelapa. Desa Lombong Timur terdiri dari empat dusun : dusun Mosso Timur, dusun Mosso Barat, dusun Karalembang Barat dan dusun Karalembang Timur.Selain sebagai pekebun usaha tani lain masyarakat desa Lombong Timur adalah sebagai petani padi sawah, peternak dan nelayan. Terdapat 9 kelompok tani dengan bidang kegiatan yang beraneka ragam, yaitu padi, kelapa, kakao, pisang dan ternak.

Sesuai dengan Peraturan Daerah Kabupaten Majene Nomor 7 Tahun 2010 Tentang Pembentukan Desa Di Wilayah Kabupaten Majene Pada Bab IV Batas Wilayah Desa Pasal 35 ayat 24 disebutkan bahwa Desa Lombang Timur mempunyai batas-batas wilayah yaitu Sebelah Utara berbatasan dengan Desa Lombang Kecamatan Malunda; Sebelah Selatan berbatasan dengan Desa Kabiraan Kecamatan Ulumanda; Sebelah Timur berbatasan dengan Desa Ulumanda Kecamatan Ulumanda; Sebelah Barat berbatasan dengan Desa Lombang Kecamatan Malunda.

Total luas desa lombong timur sekitar $3.42 \mathrm{~km} 2$, desa lombong timur merupakan desa pemekaran dari desa lombong pada tahun 2010. Jarak desa lombong timur ke kota mamuju ( ibu kota provinsi sulawesi barat) berjarak $40 \mathrm{~km}$. Perkembangan disektor pertanian yang dominan adalah perkebunan (kelapa dalam, sawit dan kakao), sedangkan di tanaman pangan adalah padi, jagung, hortikultura (pisang, mangga) dan sektor peternakan (sapi). Jumlah kelompok tani yang ada dalam melaksanakan fungsinya ada 9 kelompok tani yaitu Kel tani Busa kaweni, kel tani pare dewanta, Kel tani matauran 1, Kel tani matauran , Kel tani pandai-pandai,Kel tani galung-galung, kel tani sinar kadita, kel tani tunas kelapa, kel tani samu sengakna, KT. Bina Mandiri.

Di desa Lombong Timur tidak ada kelompok tani yang khusus kelompok tani kelapa dalam, karena dari kelompok tani tersebut merangkap seluruh tanaman, seperti padi, kelapa, kakao, pisang, jagung, hortikultura dan ternak sapi. Jumlah anggota kelompok tani rata-rata berjumlah 25 orang anggota yang memiliki kebun kelapa dalam dengan rata-rata seluas 1 hektar, sebagian kecil ( 4-5 petani ) yang memiliki lahan kebun kelapa dalam seluas 10 ha. Secara total luas tanaman kelapa dalam sekitar 400 ha ( $80 \%$ ) dari total luas tanaman perkebunan, dan sisanya tanaman kelapa hibrida $20 \%$. Awalnya tanaman kelapa hibrida mendapat bantuan dari dinas perkebunan kabupaten sekitar tahun 1989. Sedangkan umur kelapa dalam rata-rata sekitar 30 - 45 tahun, sehingga tanaman kelapa dalam ini relatif sudah cukup tua dan perlu ada peremajaan, karena mulai terilat produksi setiap tahunnya menurun.

Pada tahun 1990 luas lahan kebun kelapa dalam di Lombong Timur sekitar 300 ha, dan pada tahun 2000 an terdapat peningkatan luas kebun menjadi 400 ha sampai tahun 2015. Informasi dari kepala desa , bahwa pada tahun 2016 ada pencetakan sawah seluas 11 ha yang merupakan alih fungsi komoditas dari lahan kelapa dalam dan kebun kakao.

\section{Pelatihan Teknologi}

Dalam mempercepat dan meningkatkan adopsi inovasi teknologi integrasi kelapa dengan ternak sapi, maka salah aspek yang dilakukan dalam pendampingan adalahmelakukan pelatihan/penyuluhan.Bentuk

penyuluhan/pelatihan yang dilakukan oleh disajikan pada Tabel 3

Diterbitkan Oleh, 
Tabel 3. Penyuluhan/pelatihan dilakukan oleh kelompok tani koperator tahun 2019

\begin{tabular}{|c|c|c|}
\hline No. & Bentuk penyuluhan/Pelatihan & Keterangan \\
\hline 1. & Pelatihan Pembuatan Minyak Kelapa & $\begin{array}{l}\text { Dilakukan pada anggota kelompok. Para anggota } \\
\text { kelompok dilatih pengolahn minyak mandar. } \\
\text { Tujuan: Agar para anggota kelompok tani mengerti } \\
\text { dan memahami teknik pembuatan minyak kelapa } \\
\text { dengan baik dan benar }\end{array}$ \\
\hline 2. & Teknlogi Pembuatan Arang tempurung & $\begin{array}{l}\text { Dilakukan dilahan. Para anggota kelompok dilatih } \\
\text { teknik pembuatan arang tempurung. Tujuan: Agar } \\
\text { para anggota kelompok tani mengerti dan memahami } \\
\text { teknik pembuatan arang tempurung dengan baik dan } \\
\text { benar }\end{array}$ \\
\hline 3. & $\begin{array}{l}\text { Teknologi Pembuatan Asap Cair Grade 1,2 } \\
\text { dan } 3\end{array}$ & $\begin{array}{l}\text { Dilakukan pada anggota kelompok. Para anggota di } \\
\text { bina dan diberi pemahaman tentang Pembuatan asap } \\
\text { cair grade } 1,2 \text { dan } 3 \\
\text { Tujuan : agar para petani mengetahui teknik } \\
\text { pembuatan asap cair grade } 1,2 \text { dan } 3\end{array}$ \\
\hline 4. & Teknlogi Pengolahan Kopra & $\begin{array}{l}\text { Dilakuak pada anggota kelompok } \\
\text { Tujuan: agar para anggota dapat menegtau teknik } \\
\text { pengeolahan kopra yang baik dan benar }\end{array}$ \\
\hline
\end{tabular}

\section{Karekteristik Petani Kelapa di Desa Lombong Timur}

\section{Luas lahan kelapa}

Luas lahan yang dimiliki dan yang diusahakan untuk tanaman kelapa dapat berpengaruh terhadap populasi tanaman kelapa dan produksi kelapa yang selanjutnya akan mempengaruhi pula pendapatan yang diterima petani (Setiawan, dkk 2014). Luas penguasaan lahan merupakan faktor utama dalam meningkatkaan produksi usahatani. Semakin besar luas lahan garapan semakin besar pula produksi yang dihasilkan sebaliknya semakin sempit luas garapan akan semakin kecil produksi yang dihasilkan. Menurut ukuran luas lahan kelapa di Desa Bolubung dapat terlihat pada Tabel 4.

Tabel 4. Data luas lahan di Desa Lombong Timur, Kecamatan Malunda Kab. Majene

\begin{tabular}{cccc}
\hline \multirow{2}{*}{ No } & Luas lahan (ha) & Jumlah sampel (orang) & Persentase (\%) \\
\hline 1 & $0,50-1,33$ & 25 & 33,33 \\
2 & $1,34-2,16$ & 30 & 40,00 \\
3 & $2,17-3,00$ & 20 & 26,67 \\
\hline & Jumlah & 75 & 100 \\
\hline
\end{tabular}

Pada Tabel 4. menunjukkan bahwa luas lahan minimum yang dikuasai petani adalah sebesar 0,5 hektar sedangkan luas lahan maksimum adalah 3,0 hektar rata-rata luas lahan untuk usahatani kelapa adalah sebesar 1,86 ha. Umumnya petani kelapa mengusasai lahan yang berukuran luas kurang dari 0,50-1,33 hektar, yakni sebesar $33,33 \%, 1,34-2,16$ diusahakan sebanyak 30 petani,

Diterbitkan Oleh, 
yakni sebesar 40,00\%, dan luas lahan 2,17-3,00 hektar diusahakan sebanyak 20 petani, yakni $26,67 \%$.

\section{Produksi kelapa}

Produksi merupakan hasil yang diperoleh petani pada saat panen dengan proses produksi yang menggunakan sumber daya sehingga dapat menghasilkan sesuatu berupa barang, jasa ataupun keduanya (Ruauw, dkk. 2010). Produksi kelapa dalam setahun umumnya dilakukan secara 3 kali panen dengan interval waktu tiap 4 bulan panen. Berdasarkan hasil penelitian menunjukkan bahwa rata-rata produksi yaitu sebesar 1.107,7 kg kopra per satu kali proses produksi, ini disebabkan karena luas lahan usahatani kelapa yaitu rata-rata 1,86 hektar. Kopra Pencugkilan Daging Buah Pencincangan Daging Buah 540 Luas lahan garapan yang lebih besar yang dimiliki petani dengan demikian jumlah pohon yang ditanam lebih banyak sehingga memberikan hasil produksi yang lebih besar, dengan demikian pendapatan yang diterima oleh petani dari hasil garapan lahan tersebut lebih banyak.

\section{Umur petani}

Umur Petani akan mempengaruhi kemampuan kerja fisik dalam mengelola usahataninya. Petani pada umumnya berusia muda mempunyai kemampuan fisik yang kuat serta semangat yang lebih tinggi dibandingkan petani yang berusia lebih tua rata-rata umur responden di Desa lombong Timur adalah 51,65. Lebih jelasnya data mengenai klasifikasi umur petani kelapa dalam di Desa Lombong terlihat pada Tabel 5.

Pada Tabel 5. menunjukkan bahwa ratarata umur responden penelitian di Desa Lombong Timur berada pada antara umur 34 - 64 Tahun sebanyak 60 jiwa $(80,00 \%)$, dan umur $\leq 65$ Tahun sebanyak 40 jiwa $(20,00 \%)$.

\section{Tingkat pendidikan}

Pendidikan merupakan kebutuhan pokok bagi setiap anggota masyarakat dalam peningkatan sumber daya manusia. Tingkat pendidikan akan mempengaruhi cara berpikir responden dalam melaksanakan kegiatan usahataninya, terutama dalam menerima informasi dan inovasi yang relevan dengan usahataninya.

Berdasarkan Tabel 6. menunjukkan bahwa tingkat pendidikan responden bervariasi, sebagian besar responden mempunyai tingkat pendidikan formal yang belum cukup baik yaitu tamat SD sebanyak 34 orang $(46,67 \%)$, tamat SMP sebanyak 30 orang $(40 \%)$, tamat SMA sebanyak 7 orang $(9,33 \%)$ sedangkan Diplomdan sarjana sebanyak 3 orang $(4,00 \%)$.

Tabel 5. Klasifikasi umur usahatani kelapa di Desa Lombong Timur

\begin{tabular}{cccc}
\hline No & Umur (tahun) & Jumlah (orang) & Presentase (\%) \\
\hline 1 & $34-64$ & 60 & 80,00 \\
2 & $\geq 65$ & 15 & 20,00 \\
\hline
\end{tabular}

Tabel 6. Jumlah petani berdasarkan tingkat pendidikan di Desa Lombong Timur Kecamatan Malunda Kab. Majene

\begin{tabular}{clcc}
\hline \multirow{2}{*}{ No } & Tingkat Pendidikan & Jumlah sampel (orang) & Persentase (\%) \\
\hline 1 & SD & 34 & 46,67 \\
2 & SMP & 30 & 40,00 \\
3 & SMA & 7 & 9,33 \\
4 & D3/S1 & 3 & 4,00 \\
\hline \multicolumn{2}{c}{ Jumlah } & 75 & 100 \\
\hline
\end{tabular}

Diterbitkan Oleh, 


\section{Jumlah tanggungan keluarga}

Jumlah tanggungan keluarga juga akan mempengaruhi biaya yang dikeluarkanpetani dalam menghidupi keluarganya. Data tanggungan keluarga pada usahatani kelapa di Desa Lombong Timur . terlihat pada Tabel 7. Tabel 7. menunjukkan bahwa rata rata jumlah tanggungan keluarga responden petani dan pedagang di Desa Lombong Timur antara $1-2$ sebanyak 35 jiwa
(46,67\%), jumlah tanggungan keluarga $3-4$ sebanyak 25 jiwa $(33,33 \%)$, dan jumlah tanggungan keluarga $5-6$ sebanyak 15 jiwa $(20,00 \%)$. Tanggungan keluarga yang produktif bagi petani merupakan sumber tenaga kerja yang utama untuk menunjang kegiatan usahanya, karena selama pekerjaan masih dapat dilakukan oleh keluarga akan mengurangi pengeluaran upah tenaga.

Tabel 7. Klasifikasi jumlah tanggungan keluarga responden di Desa Bolubung Kecamatan Bulagi Utara Kabupaten Banggai Kepulauan

\begin{tabular}{clcc}
\hline No & Jumlah Tanggungan & Keluarga Jumlah sampel (orang) & Persentase (\%) \\
\hline 1 & $1-2$ & 35 & 46,67 \\
2 & $3-4$ & 25 & 33,33 \\
3 & $5-6$ & 15 & 20,00 \\
\hline & Jumlah & 75 & 100 \\
\hline
\end{tabular}

\section{Diversifikasi Olahan Produk Kelapa Dalam}

\section{Pengolahan kopra}

Kopra adalah daging buah kelapa yang dikeringkan. Kopra merupakan salah satu produk turunan kelapa yang sangat penting, karena merupakan bahan baku pembuatan minyak kelapa yang digunakan dalam kebutuhan sehari-hari dan juga digunakan sebagai obat tradisional dan kecantikan. Kopra juga mempunyai daya jual yang lebih tinggi dari pada kelapa mentah. Daging kelapa didapat dengan mencungkil dari tempurung secara manual atau memakai mesin cungkil kopra kemudian dikeringkan dengan bantuan sinar matahari atau panas buatan. Sementara petani kelapa di Desa Lombong Timur membuat kopra masih mempergunakan teknologi yang sangat sederhana atau masih mempergunakan kebiasaan turun temurun. Adapun cara yang biasa dilakukan dalam pembuatan kopra dimulai dengan memanen kelapa dengan cara memanjat atau menunggu jatuh sendiri. Kelapa hasil panen dikupas/dicukil untuk diambil dagingnya kemudian daging tersebut dijemur diatas terpal. Pada musim kemarau biasanya dijemur dihalaman samping atau depan rumah selama 2 sampai 3 hari. Dengan menjemur seperti itu menjadikan kopra terkontaminasi kotoran seperti debu sehingga menurunkan kualitas kopra itu sendiri. Selain dijemur pembuatan kopra bisa dilakukan dengan cara pembakaran.

Tempat pembakaran daging kelapa di dalam desa biasa dilakukan ditempat yang sudah semuanya dibeton (permanen). Bisa juga dibakar ditempat yang semi permanen, hanya temboknya yang disemen setinggi 1 meter sementara tutupnya pakai kawat bronjong. Bisa juga dibakar di tempat sederhana yang hanya mempergunakan kawat bronjong. Walaupun tempat pembakaran bisa berbeda beda tetapi untuk bahan bakarnya mempergunakan bahan yang sama, yaitu sabut kelapa. Teknik membuat kopra yang biasa digunakan petani tidak bisa mengurangi kadar air dan kadar air yang dihasilkan dengan cara tradisional tersebut berkisar antara 11-12 persen. Kopra yang baik, sebaiknya hanya memiliki kandungan air 6\% - 7\% agar tidak mudah terserang organisme pengganggu. Serangan tersebut mudah terjadi jika kadar air dalam kopra tinggi. Bagi pedagang kadar air ini dipergunakan untuk menjatuh harga jual kopra. Agar bisa membantu petani dalam menambah pendapatan hasil menjual kopra, maka cara pengolahan kopra di petani harus dirubah.

Diterbitkan Oleh, 
Perubahan ini dimulai pada kegiatan mencungkil daging kelapa dengan mempergunakan mesin khusus mencungkil daging kelapa. Daging kelapa tersebut kemudian dijemur dengan cara : (i) pengeringan dengan sinae matahari, penjemuran sebaiknya jangan 2-3 hari tetapi antara 5 sampai 7 hari. (ii) Pengeringan dengan tudung plastik, Modifikasi dari penjemuran sinar matahari, tetapi memanfaatkan tudung plastik, kopra dijemur dalam areal plastik. Panas yang masuk ke dalam areal plastik akan bertahan lama sehingga penjemuran bisa lebih cepat dari penjemuran biasa. Teknik penjemuran ini lebih baik dari cara penjemuran matahari langsung. (iii) Pengeringan dengan pengasapan, Cara ini adalah teknik yang banyak berkembang di petani kopra. Daging Kelapa dimasukkan ke dalam parapara tungku pengasapan dengan membakar sabut kelapa atau tempurung dibawahnya. Teknik ini membutuhkan waktu kurang lebih 3 hari. (iv) Pengeringan menggunakan oven, Teknik pengeringan kopra ini adalah yang terbaik untuk menghasilkan kopra. Teknik yang dipakai adalah model Lade oven. Prosesnya adalah kelapa basah disusun dalam lemari oven yang telah tersedia, kemudian dipanasi dalam kondisi tertutup; ke dalam ruangan ini dialirkan panas dengan suhu 40 derajat Celcius sampai 80 derajat Celcius. Panas dihasilkan dari pembakaran biomassa yang menghasilkan asap dan panas, kemudian dialirkan oleh blower untuk mengaliri oven pengering kopra.

Secara tradisional, penggunaan produk kelapa adalah untuk konsumsi segar, dibuat kopra atau minyak kelapa. Menurut Somaatmadja (1984), berdasarkan angka tahun 1970-an sekitar 34,7\% dari produksi kelapa digunakan untuk pembuatan santan, 8\% untuk pembuatan minyak klentik (tradisional) dan 57,3\% untuk pembuatan kopra (Awang, 1991). Sebagian besar petani kelapa di Desa Lombong Timur, Kecamatam Lombong Timur melakukan pengolahan kelapa menjadi kopra Dalam $1 \mathrm{~kg}$ kopra membutuhkan biji kelapa sebanyak 4-6 buah kelapa. Petani di Desa Lombog Timur menjadikan usahatani kopra sebagai pekerjaan utama dikarenakan wilayah ini juga telah lama dikhususkan untuk pertanian tanaman kelapa.

Tabel. 8. Data usaha tani kopra di Desa Lombong Timur, 2019

\begin{tabular}{lccc}
\hline \multicolumn{1}{c}{ Dusun } & Nama Kelompok Tani & Jumlah Anggota & Pengolahan Kopra \\
\hline Mosso Barat & Tani Burak weni & 25 & 1 unit \\
Karalembang Barat & Pande-pande & 25 & 1 unit \\
Karalembang Timur & Galung & 25 & 1 unit \\
\hline Jumlah & & 75 & 3 unit \\
\hline
\end{tabular}

Buah kelapa terdiri atas kulit atau sabut kelapa, tempurung, daging dan air kelapa. Kopra adalah daging kelapa yang dicungkil dari tempurung secara manual dan kemudian dikeringkan dengan pengasapan. Proses pengolahan kelapa menjadi kopra, sabut dan tempurung kelapa terlebih dahulu dikupas, setelah dikupas kelapa kemudian dibelah. Tujuan penghilangan sabut dan pembelahan buah adalah untuk memudahkan proses selanjutnya sekaligus mengeluarkan air buah Alat untuk pengupasan disebut lewang. Buah kelapa yang masih bertempurung dibelah menjadi dua dengan mengunakan parang. Kelapa yang sudah dibelah kemudian dilakukan pengasapan dengan cara meletakkan daging kelapa di atas kerangka kawat setinggi 1-1,5 di atas tanah, saat pengasapan bagian terbuka dari kelapa diletakkan menghadap ke bawah atau ke arah sumber asap. pengasapan dengan membakar sabut kelapa atau tempurung dibawahnya membutuhkan waktu 3 harian. Hasil dari pengasapan buah kelapa menghasilkan kopra, setelah didinginkan kemudian dilakukan pencungkilan daging buah (kopra) yaitu mengeluarkan daging buah dari tempurung kelapa dengan alat pengkore. Kopra kemudian dicincang hingga beberapa potong. Kopra selanjutnya dikemas dalam karung yang telah disediakan oleh petani, kemudian dipasarkan kepedangan pengumpul untuk berbagai keperluan.

Diterbitkan Oleh, 
Dari hasil Kegiatan total hasil produksi kopra siap jual yang diperoleh kelompok tani bioindustri kelapa dalam pada tahun 2019 sebanyak $43.234 \mathrm{~kg}$ (Tabel 9). Hasil tersebut berasal hasil produksi dari 3 unit tempat pengasapan yang dikelola oleh sebanyak 3 kelompok tani yang bergabung. Hasil korpra tersebut diperoleh dari gabungan atau total akumulasi bulan januaridesember 2019. Kelompok tani yang memperoleh hasil kopra tertinggi secara berurutan adalah kelompok tani "Galung", kemudian kelompok tani "Mata Ure" dan "Pande-pande". Produksi Kopra kelompok tani bioindustri yang diperoleh merupakan sumber utama pendapatan anggota kelompok tani yang terlibat. Nilai hasil produksi kopra petani yang diperoleh total sebanyak Rp.259.404.000,- (Tabel 9). Nilai produksi tersebut diperoleh dari total produksi seluruh kelompok sebanyak $43.234 \mathrm{~kg}$ dengan harga jual ditingkat pedagang lokal seharga Rp. $6.000 / \mathrm{kg}$. Jika dirata-ratakan, maka tingkat pendapatan kotor setiap kelompok/per unit tempat pengasapan dari hasil penjualan produksi Kopra sebesar Rp. 86.468.000/kelompok. Tingkat pendapat tersebut tergolong cukup tinggi karena hanya diperoleh pengolahan Kopra dan sumber tambahan pendapatan masih ada dari pengelolaan produksi pengolahan arang tempurung, pengelolaan minyak kelapa. Kelompok tani bioindustri yang mempunyai pendapatan tertinggi hasil penjualan Kopra adalah adalah kelompok tani "Galung" kemudian "Mataure" dan Pande-pande.

\section{Minyak kelapa}

Hasil pemasakan dari minyak kelapa adalah minyak kelapa yang disebut oleh masyarakat setempat minyak mandar. Cara pembuatan minyak kelapa adalah santan kelapa dimasak sekitar 5 - 6 jam tergantung kapasitas santan yang dimasak. Bahannya adalah 50 butir kelapa dalam akan menghasilkan 8 liter minyak kelapa. yang membuat minyak goreng hanya untuk konsumsi rumahtangga, belum bersifat komersial, dan mengusahakannya juga relatif sedikit sekitar 10 persen terhadap total petani kebun kelapa. Adapun pembuatan minyak goreng hanya satu bulan sekali. Proses pengolahan minyak kelapa dilakukan dengan

Diterbitkan Oleh, Unit Penelitian dan Pengabdian Masyarakat, Politeknik Pembangunan Pertanian Gowa http://ejournal.polbangtan-gowa.ac.id cara pemanasan langsung dengan suhu tinggi. Cara ini menghasilkan minyak kelapa kualitas rendah, karena kandungan air dan asam lemak bebas tinggi yakni masing-masing $0.37 \%$ dan $5.37 \%$, sehingga minyak kelapa lebih cepat menjadi tengik, dengan warna kecoklatan dan daya simpan menjadi lebih pendek (sekitar 35 hari). Untuk menghilangkan bau tengik, minyak menjadi tahan lama dan mengurangi bau khas minyak kampung dengan cara : minyak dipanaskan sampai suhu 70-90 C, masukkan larutan $\mathrm{NaOH} 4 \mathrm{M}$ ke dalam minyak, aduk hingga mengeluarkan busa dan terakhir disaring.

Kelapa dengan kualitas rendah berpeluang untuk dijadikan minyak oleh petani dengan teknologi sederhana yaitu memisahkan bakal minyak (krim dan skim) dengan air melalui penambahan emzim bromelin hanya butuh waktu +3 jam, sehingga mutu minyak goreng yang dihasilkan relatif baik dan tidak tengik. Dengan pemakaian enzim bromelin (sari buah nenas $50 \mathrm{ml} / \mathrm{kg}$ parutan kelapa), bakal minyak(skim dan krim) yang ada pada larutan santan dapat dipisahkan dari air dalam waktu yang reltif pendek (+ 3 jam). Untuk mendapatkan minyak kita hanya memanaskan skim dan krim dalam waktu yang relative pendek $(+1,5 \mathrm{jam})$. Metode pembuatannya sebagai berikut: pilih kelapa yang tua dan segar, kemudian aging kelapa diparut, timbang sebanyak $8 \mathrm{~kg}$ kelapa parut, tambahkan 16 liter air dan diperas hingga keluar santannya, siapkan nenas yang sudah matang dikupas kulitnya dan dibuang matanya, parutlah nenas hingga terbentuk parutan nenas, kemudian diperas dengan kain saring (tanpa penambahan air) hingga diperoleh sari buah nenas, ambahkan kedalam santan dan diaduk hingga rata, asukkan ke dalam botol aqua yang punya kran pembuang air, biarkan selama lebih kurang 3 jam hingga air dan bakal minyak (krim dan skim), buang airnya perlahan-lahan dengan cara membuka kran, sisa santan/bakal minyak (krim dan skim) kemudian dimasak dalam kuali dengan memakai tungku anglo (hemat bahan bakar kayu) sampai terbentuk minyak,minyak yang didapat kemudian disaring dengan kain saring2-3 kali. 
Tabel. 9. Data produksi dan pendapatan produk kopra Desa Lombong Timur, tahun 2019

\begin{tabular}{|c|c|c|c|c|c|c|c|c|c|c|c|c|}
\hline \multirow[b]{2}{*}{ No. } & \multirow[b]{2}{*}{ Bulan } & \multicolumn{3}{|c|}{ KT MATA URE } & \multicolumn{3}{|c|}{ KT Pande-Pande } & \multicolumn{3}{|c|}{ Kt Galung } & \multicolumn{2}{|c|}{ Total } \\
\hline & & $\begin{array}{l}\text { Produksi } \\
\quad(\mathrm{kg})\end{array}$ & $\begin{array}{c}\text { Harga } \\
\text { Jual } \\
\text { (per/kg) }\end{array}$ & Hasil jual & $\begin{array}{l}\text { Produksi } \\
\quad(\mathrm{kg})\end{array}$ & $\begin{array}{c}\text { Harga } \\
\text { Jual } \\
\text { (per/kg) }\end{array}$ & Hasil jual & $\begin{array}{l}\text { Produksi } \\
\quad(\mathrm{kg})\end{array}$ & $\begin{array}{c}\text { Harga } \\
\text { Jual } \\
\text { (per/kg) }\end{array}$ & Hasil jual & Produksi & $\begin{array}{c}\text { Hasil } \\
\text { Penjualan }\end{array}$ \\
\hline 1 & Januari & 1.058 & 6.000 & 6.348 .000 & 1.265 & 6.000 & 7.590 .000 & 1.518 & 6.000 & 9.108 .000 & 3.841 & 23.046 .000 \\
\hline 2 & Februari & 1.219 & 6.000 & 7.314 .000 & 1.311 & 6.000 & 7.866 .000 & 1.196 & 6.000 & 7.176 .000 & 3.726 & 22.356 .000 \\
\hline 3 & Maret & 1.219 & 6.000 & 7.314 .000 & 1.196 & 6.000 & 7.176 .000 & 1.150 & 6.000 & 6.900 .000 & 3.565 & 21.390 .000 \\
\hline 4 & April & 1.288 & 6.000 & 7.728 .000 & 1.242 & 6.000 & 7.452 .000 & 1.173 & 6.000 & 7.038 .000 & 3.703 & 22.218 .000 \\
\hline 5 & Mei & 1.219 & 6.000 & 7.314 .000 & 1.035 & 6.000 & 6.210 .000 & 1.311 & 6.000 & 7.866 .000 & 3.565 & 21.390 .000 \\
\hline 6 & Juni & 1.196 & 6.000 & 7.176 .000 & 1.058 & 6.000 & 6.348 .000 & 1.265 & 6.000 & 7.590 .000 & 3.519 & 21.114 .000 \\
\hline 7 & Juli & 1.196 & 6.000 & 7.176 .000 & 989 & 6.000 & 5.934 .000 & 1.288 & 6.000 & 7.728 .000 & 3.473 & 20.838 .000 \\
\hline 8 & Agustus & 1.219 & 6.000 & 7.314 .000 & 1.058 & 6.000 & 6.348 .000 & 1.058 & 6.000 & 6.348 .000 & 3.335 & 20.010 .000 \\
\hline 9 & September & 1.219 & 6.000 & 7.314 .000 & 1.035 & 6.000 & 6.210 .000 & 1.288 & 6.000 & 7.728 .000 & 3.542 & 21.252 .000 \\
\hline 10 & Oktober & 1.173 & 6.000 & 7.038 .000 & 1.035 & 6.000 & 6.210 .000 & 1.357 & 6.000 & 8.142 .000 & 3.565 & 21.390 .000 \\
\hline 11 & Nopember & 1.219 & 6.000 & 7.314 .000 & 1.334 & 6.000 & 8.004 .000 & 1.403 & 6.000 & 8.418 .000 & 3.956 & 23.736 .000 \\
\hline \multirow[t]{3}{*}{12} & Desember & 1.190 & 6.000 & 7.140 .000 & 1.035 & 6.000 & 6.210 .000 & 1.219 & 6.000 & 7.314 .000 & 3.444 & 20.664 .000 \\
\hline & Jumlah & 14.415 & - & 86.490 .000 & 13.593 & - & 81.558 .000 & 15.226 & - & 91.356 .000 & 43.234 & 259.404 .000 \\
\hline & Rata-Rata & 1.201 & - & 7.207 .500 & 1.133 & - & 6.796 .500 & 1.269 & - & 7.613 .000 & 14.411 & 86.468 .000 \\
\hline
\end{tabular}

Dari hasil Kegiatan total hasil produksi minyak kelapa siap jual yang diperoleh kelompok tani bioindustri kelapa dalam pada tahun 2019 sebanyak 10.795 Liter (Tabel 10). Hasil tersebut berasal hasil produksi dari 3 kelompok tani yang bergabung. Hasil minyak kelapa tersebut diperoleh dari gabungan atau total akumulasi bulan januari-desember 2019. Kelompok tani yang memperoleh hasil minyak kelapa tertinggi secara berurutan adalah kelompok tani "pande-pande", kemudian kelompok tani "galung" dan "Mataure". Produksi minyak kelapa kelompok tani bioindustri yang diperoleh merupakan usahaa tambahan anggota kelompok tani yang terlibat. Nilai hasil produksi minyak kelapa kelompok petani yang diperoleh total sebanyak Rp.161.925.000,- (Tabel 10). Nilai produksi tersebut diperoleh dari total produksi seluruh kelompok sebanyak 10.795 liter dengan harga jual ditingkat pedagang lokal seharga Rp. 15.000/liter. Jika dirata-ratakan, maka tingkat pendapatan kotor setiap kelompok tempat pengasapan dari hasil penjualan produksi Kopra sebesar Rp. 13.493.750/kelompok. Tingkat pendapat tersebut tergolong cukup tinggi karena hanya diperoleh pengolahan minyak kelapa dan sumber tambahan pendapatan masih ada dari pengelolaan produksi pengolahan arang 
tempurung, pengelolaan kopra. Kelompok tani bioindustri yang mempunyai pendapatan tertinggi hasil penjualan minyak kelaoa adalah adalah kelompok tani "pande-pande" kemudian "galung" dan "mataure".

\section{Arang tempurung kelapa}

Batok kelapa atau tempurung bisa dijadikan arang dengan mempergunakan dua metode, yaitu dengan cara dibakar dengan mempergunakan drum aspal atau dibakar dengan cara membuat lubang tanah sedalam 1 meter. Cara membuat dengan menggunakan drum aspal antara lain dimulai dari menyiapkan drum bekas yang telah dilubangi bagian bawahnya sebanyak 8 buah lubang. tempurung (batok) kelapa disusun ke dalam drum tadi kira-kira $1 / 4$ bagian. Setelah tersusun kemudian arang dibakar sampai menyala. Setelah tempurung (batok) kelapa menyala semua, masukkan kembali tempurung (batok) kelapa $1 / 4$ bagian lagi dan seterusnya hingga penuh. Setelah terbakar semua, kemudian tutup dengan plat besi yang dilapisi dengan tanah liat.

Tabel. 10. Data produksi dan pendapatan produk minyak kelapa Desa Lombong Timur, tahun 2019

\begin{tabular}{|c|c|c|c|c|c|c|c|c|c|c|c|c|}
\hline \multirow[b]{2}{*}{ No. } & \multirow[b]{2}{*}{ Bulan } & \multicolumn{3}{|c|}{ KT MATA URE } & \multicolumn{3}{|c|}{ KT Pande-Pande } & \multicolumn{3}{|c|}{ Kt Galung } & \multicolumn{2}{|c|}{ Total } \\
\hline & & $\begin{array}{l}\text { Produksi } \\
\text { (liter) }\end{array}$ & $\begin{array}{c}\text { Harga } \\
\text { Jual } \\
\text { (per/liter) }\end{array}$ & Hasil jual & $\begin{array}{l}\text { Produksi } \\
\quad \text { (liter) }\end{array}$ & $\begin{array}{c}\text { Harga } \\
\text { Jual } \\
\text { (per/liter) }\end{array}$ & Hasil jual & $\begin{array}{l}\text { Produksi } \\
\text { (liter) }\end{array}$ & $\begin{array}{c}\text { Harga } \\
\text { Jual } \\
\text { (per/liter) }\end{array}$ & Hasil jual & Produksi & $\begin{array}{c}\text { Hasil } \\
\text { Penjualan }\end{array}$ \\
\hline 1 & Januari & 300 & 15.000 & 4.500 .000 & 275 & 15.000 & 4.125 .000 & 320 & 15.000 & 4.800 .000 & 895 & 13.425 .000 \\
\hline 2 & Februari & 350 & 15.000 & 5.250 .000 & 300 & 15.000 & 4.500 .000 & 370 & 15.000 & 5.550 .000 & 1.020 & 15.300 .000 \\
\hline 3 & Maret & 250 & 15.000 & 3.750 .000 & 240 & 15.000 & 3.600 .000 & 330 & 15.000 & 4.950 .000 & 820 & 12.300 .000 \\
\hline 4 & April & 340 & 15.000 & 5.100 .000 & 330 & 15.000 & 4.950 .000 & 320 & 15.000 & 4.800 .000 & 990 & 14.850 .000 \\
\hline 5 & Mei & 330 & 15.000 & 4.950 .000 & 310 & 15.000 & 4.650 .000 & 320 & 15.000 & 4.800 .000 & 960 & 14.400 .000 \\
\hline 6 & Juni & 300 & 15.000 & 4.500 .000 & 275 & 15.000 & 4.125 .000 & 310 & 15.000 & 4.650 .000 & 885 & 13.275 .000 \\
\hline 7 & Juli & 200 & 15.000 & 3.000 .000 & 375 & 15.000 & 5.625 .000 & 300 & 15.000 & 4.500 .000 & 875 & 13.125 .000 \\
\hline 8 & Agustus & 300 & 15.000 & 4.500 .000 & 340 & 15.000 & 5.100 .000 & 200 & 15.000 & 3.000 .000 & 840 & 12.600 .000 \\
\hline 9 & September & 200 & 15.000 & 3.000 .000 & 370 & 15.000 & 5.550 .000 & 250 & 15.000 & 3.750 .000 & 820 & 12.300 .000 \\
\hline 10 & Oktober & 350 & 15.000 & 5.250 .000 & 250 & 15.000 & 3.750 .000 & 350 & 15.000 & 5.250 .000 & 950 & 14.250 .000 \\
\hline 11 & Nopember & 230 & 15.000 & 3.450 .000 & 350 & 15.000 & 5.250 .000 & 300 & 15.000 & 4.500 .000 & 880 & 13.200 .000 \\
\hline \multirow[t]{3}{*}{12} & Desember & 200 & 15.000 & 3.000 .000 & 360 & 15.000 & 5.400 .000 & 300 & 15.000 & 4.500 .000 & 860 & 12.900 .000 \\
\hline & Jumlah & 3.350 & - & 50.250 .000 & 3.290 & - & 56.625 .000 & 3.290 & - & 55.050 .000 & 10.795 & 161.925 .000 \\
\hline & Rata-Rata & 279 & - & 4.187 .500 & 274 & - & 4.718 .750 & 274 & - & 4.587 .500 & 3.598 & 53.975 .000 \\
\hline
\end{tabular}

Diterbitkan Oleh, 
Pembuatan dengan menggunakan lubang dimulai dengan menyiapkan tempurung kelapa yang sudah kering. Membuat lubang pada tanah yang kering dengan ukuran kedalaman $1-2$ meter dan panjang $75-100 \mathrm{~cm}$ dan lebar $75-100$ $\mathrm{cm}$. Pada dasar lubang digunakan batu bata sebagai alas lubang agar api tahan lama. Pada dasar lubang susunlah kayu kering, lalu bakar. Setelah api agak besar masukkan tumpurung kelapa (batok kelapa) yang telah bersih dari sabut kira-kira $1 / 4$ bagian lubang. Jika tempurung (batok) kelapa sudah terbakar semua, kemudian masukkan tempurung lagi $1 / 4$ bagian dan seterusnya sampai penuh. Setelah tempurung terbakar semua, permukaan lubang cepat ditutup dengan kayu, pelepah pisang atau tanah bekas galian.

Di Desa Lombong Timur tenaga kerja yang mengolah tempurung/batok kelapa ada sekitar 4 orang (pembakaran dengan drum) dan 2 orang tempat pembakaran dengan tanah. Kelemahan dan keuntungan dari dua metode ini dapat dilihat pada tabel 3 dibawah ini. Cara membuat arang secara tradisional pada umumnya tidak menghasilkan arang yang berkualitas. Kualitas arang yang diinginkan oleh industri adalah arang yang memiliki kadar air rendah, kandungan minyak terbang masih tinggi, serta daya ikat karbon juga tinggi. Arang seperti itu banyak diminati antara lain oleh :industri pengolahan makanan, pengolahan air bersih, sistem filterisasi air pada kolam koi, industri baterai kering, dan industri kosmetik.

Cara membuat arang dengan mempersiapkan drum berkapasitas 200 liter. Supaya bisa menghasilkan arang berkualitas tinggi, drum ini perlu dimodifikasi. Drum dibagi menjadi 4 bagian: bagian bawah dibuat terbuka, bagian atasnya terutup, tapi bisa dibuka, bagian cerobong, dan lubang-lubang udara di badan drum. Untuk bagian cerobong, buat lubang berdiameter $10 \mathrm{~cm}$ di bagian atas drum yang tertutup. Pasangkan cerobong setinggi $30 \mathrm{~cm}$ pada lubang tersebut. Bahan untuk membuat cerobong ini bisa dari seng, aluminum, atau bahan-bahan logam lainnya. Untuk bagian tubuh drum, buat 3 lubang yang dibuat berbaris mengelilingi drum. Tiap baris terdiri dari 4 lubang yang berdiameter $13 \mathrm{~mm}$. Jarak antar baris dibuat sepanjang $30 \mathrm{~cm}$. Setelah alat pembakaran arang tempurung kelapa telah siap, saatnya mulai membakar bahan bakunya, yaitu batok kelapa. Masukkan batok kelapa ke dalam drum, lalu dimulai pembakaran, buka semua lubang-lubang yang ada di badan drum, tutup bagian atasnya, biarkan sampai membara, tapi tidak sampai timbul api. Asap akan keluar melalui cerobong asap selama pembakaran berlangsung. Biarkan proses pendinginan berlangsung secara alami. Jangan sekali-kali memadamkan bara api dengan air karena akan menghasilkan arang yang tak matang atau cacat. Setelah pendinginan selesai, keesokannya dibongkar dan hasilnya berupa arang yang hitam legam.

Dari hasil Kegiatan total hasil produksi Arang tempurung kelapa siap jual yang diperoleh kelompok tani bioindustri kelapa dalam pada tahun 2019 sebanyak $11.326 \mathrm{~kg}$ (Tabel 11). Hasil tersebut berasal hasil produksi dari 3 kelompok tani yang bergabung. Hasil Arang tempurung kelapa tersebut diperoleh dari gabungan atau total akumulasi bulan januari-desember 2019. Kelompok tani yang memperoleh hasil Arang Tempurung tertinggi secara berurutan adalah kelompok tani "galung", kemudian kelompok tani "Mataure" dan " Pande-pande". Produksi Arang tempurung kelapa kelompok tani bioindustri yang diperoleh merupakan usaha tambahan anggota kelompok tani yang terlibat. Nilai hasil produksi arang tempurung kelapa kelompok petani yang diperoleh total sebanyak Rp. 45.304,000,- (Tabel 11). Nilai produksi tersebut diperoleh dari total produksi seluruh kelompok sebanyak $11.326 \mathrm{~kg}$ dengan harga jual ditingkat pedagang lokal seharga Rp. 4.000/kg. Jika dirata-ratakan, maka tingkat pendapatan kotor setiap kelompok tempat pengasapan dari hasil penjualan produksi Kopra sebesar Rp. 15.101.333/kelompok.

Diterbitkan Oleh, 
Tabel. 11. data produksi dan pendapatan produk arang tempurung Desa Lombong Timur, tahun 2019

\begin{tabular}{|c|c|c|c|c|c|c|c|c|c|c|c|c|}
\hline \multirow[b]{2}{*}{ No. } & \multirow[b]{2}{*}{ Bulan } & \multicolumn{3}{|c|}{ KT MATA URE } & \multicolumn{3}{|c|}{ KT Pande-Pande } & \multicolumn{3}{|c|}{ Kt Galung } & \multicolumn{2}{|c|}{ Total } \\
\hline & & $\begin{array}{l}\text { Produksi } \\
\quad(\mathrm{kg})\end{array}$ & $\begin{array}{c}\text { Harga } \\
\text { Jual } \\
\text { (per/kg) }\end{array}$ & Hasil jual & $\begin{array}{l}\text { Produksi } \\
\quad(\mathrm{kg})\end{array}$ & $\begin{array}{c}\text { Harga } \\
\text { Jual } \\
\text { (per/kg) }\end{array}$ & Hasil jual & $\begin{array}{l}\text { Produksi } \\
\quad(\mathrm{kg})\end{array}$ & $\begin{array}{c}\text { Harga } \\
\text { Jual } \\
\text { (per/kg) }\end{array}$ & Hasil jual & Produksi & $\begin{array}{c}\text { Hasil } \\
\text { Penjualan }\end{array}$ \\
\hline 1 & Januari & 276 & 4.000 & 1.104 .000 & 330 & 4.000 & 1.320 .000 & 396 & 4.000 & 1.584 .000 & 1.002 & 4.008 .000 \\
\hline 2 & Februari & 318 & 4.000 & 1.272 .000 & 342 & 4.000 & 1.368 .000 & 312 & 4.000 & 1.248 .000 & 972 & 3.888 .000 \\
\hline 3 & Maret & 318 & 4.000 & 1.272 .000 & 312 & 4.000 & 1.248 .000 & 300 & 4.000 & 1.200 .000 & 930 & 3.720 .000 \\
\hline 4 & April & 336 & 4.000 & 1.344 .000 & 324 & 4.000 & 1.296 .000 & 306 & 4.000 & 1.224 .000 & 966 & 3.864 .000 \\
\hline 5 & Mei & 318 & 4.000 & 1.272 .000 & 270 & 4.000 & 1.080 .000 & 342 & 4.000 & 1.368 .000 & 930 & 3.720 .000 \\
\hline 6 & Juni & 312 & 4.000 & 1.248 .000 & 276 & 4.000 & 1.104 .000 & 330 & 4.000 & 1.320 .000 & 918 & 3.672 .000 \\
\hline 7 & Juli & 312 & 4.000 & 1.248 .000 & 258 & 4.000 & 1.032 .000 & 336 & 4.000 & 1.344 .000 & 906 & 3.624 .000 \\
\hline 8 & Agustus & 318 & 4.000 & 1.272 .000 & 276 & 4.000 & 1.104 .000 & 376 & 4.000 & 1.504 .000 & 970 & 3.880 .000 \\
\hline 9 & September & 318 & 4.000 & 1.272 .000 & 270 & 4.000 & 1.080 .000 & 336 & 4.000 & 1.344 .000 & 924 & 3.696 .000 \\
\hline 10 & Oktober & 306 & 4.000 & 1.224 .000 & 270 & 4.000 & 1.080 .000 & 354 & 4.000 & 1.416 .000 & 930 & 3.720 .000 \\
\hline 11 & Nopember & 318 & 4.000 & 1.272 .000 & 348 & 4.000 & 1.392 .000 & 366 & 4.000 & 1.464 .000 & 1.032 & 4.128 .000 \\
\hline \multirow[t]{3}{*}{12} & Desember & 258 & 4.000 & 1.032 .000 & 270 & 4.000 & 1.080 .000 & 318 & 4.000 & 1.272 .000 & 846 & 3.384 .000 \\
\hline & Jumlah & 3.708 & - & 14.832 .000 & 3.546 & - & 14.184 .000 & 4.072 & - & 16.288 .000 & 11.326 & 45.304 .000 \\
\hline & Rata-Rata & 309 & - & 1.236 .000 & 296 & - & 90.000 & 339 & - & 1.357 .333 & 3.775 & 15.101 .333 \\
\hline
\end{tabular}

\section{Penerimaan Kelompok Tani Bioindustri Kelapa}

Penerimaan kelompok sebagai pendapatan diperoleh dari hasil penjualan produk antara lain kopra, minyak kelapa dan Arang tempurung. Tingkat penerimaan kotor kelompok tani dari hasil usaha kegiatan bioindustri Kelapa di Sulawesi Barat selama tahun 2019 disajikan pada Tabel 12. Nilai total penerimaan kotor

Diterbitkan Oleh,

Unit Penelitian dan Pengabdian Masyarakat, Politeknik Pembangunan Pertanian Gowa

http://ejournal.polbangtan-gowa.ac.id kelompok tani bioindustri kakao pada tahun 2019 sebesar Rp.466.633.000,- dengan rata-rata penerimaan setiap kelompok Rp. 155.544.333,- Jumlah kelompok keseluruhan sebanyak 3 kelompok. Dari total penerimaan kotor yang ada, hasil penjualan kopra memberikan penerimaan tertinggi (RP. 259.404.000), kemudian penjualan minyak kelapa (Rp. 161.925.000,-), dan penjualan Arang Tempurung (Rp. 45.304.000,). 
Tabel. 11. Nilai penjualan hasil usahan pengolahan kelapa Desa Lombong Timur, tahun 2019

\begin{tabular}{crrrrr}
\hline \multirow{2}{*}{ No } & Nama Keltan & \multicolumn{2}{c}{ Nilai Penjualan Hasil Usaha (Rp/tahun) } & \multirow{2}{*}{$\begin{array}{c}\text { Total Nilai } \\
\text { Penjualan (RP) }\end{array}$} \\
\cline { 3 - 5 } & & \multicolumn{1}{l}{ Kopra } & $\begin{array}{c}\text { Arang } \\
\text { Tempurung }\end{array}$ & Minyak Kelapa & \\
\hline 1 & KT Mata Ure & 86.490 .000 & 14.832 .000 & 50.250 .000 & 151.572 .000 \\
2 & KT Pande-pande & 81.558 .000 & 14.184 .000 & 56.625 .000 & 152.367 .000 \\
3 & KT Galung & 91.356 .000 & 16.288 .000 & 55.050 .000 & 162.694 .000 \\
\hline & Jumlah & 259.404 .000 & 45.304 .000 & 161.925 .000 & 466.633 .000 \\
\hline & Rata-rata & 86.468 .000 & 15.101 .333 & 53.975 .000 & 155.544 .333 \\
\hline
\end{tabular}

Kelompok tani yang memberikan sumbangan penerimaan terbesar adalah kelompok tani Galung, kemudian kelompok tani PandePande, dan yang paling rendah adalah kelompok tani Mata Ure. Tingkat penerimaan yang besar oleh kelompok tani bersumber dari hasil penjualan Kopra dan Minyak Kelapa. Sedangkan penerimaan dari penjualan arang tempurng masih relatif rendah. Rendahnya penjualan Arang tempurung disebabkan drum pembakar masih kurang sehingga produksi arang yang dihasilkan masih rendah setiap bulannya.

\section{KESIMPULAN}

Kesimpulan Sementara dari pelaksanaan kegiatan Model Pertanian Bioindustri Kelapa Dalam adalah sebagai berikut:

1. Jumlah kelompok tani yang terlibat dalam kegiatan sebanyak 3 (tiga) kelompok dengan jumlah anggota petani sebanyak 75 orang. Tingkat pendidikan rata-rata dari SD - S1 dengan umur rata-rata 41,63 tahu. Lahan kelapa anggota kelompok yang termasuk dalam kegiatan bioindustri seluas 35,25 ha dengan rata-rata kepemilikan 1,33 ha setiap anggota.

2. Pengelolaan Kelapa dalam oleh anggota kelompok tani telah memproduksi atau menghasilkan kopra sebesar $43.234 \mathrm{~kg}$ dengan tingkat nilai penerimaan sebesar Rp. 259.404.000,-, Minyak Kelapa sebesar 10.795 liter dengan tingkat nilai penerimaan sebesar Rp. 161.925.000 dan pengeolahan arang tempurung sebesar $11.326 \mathrm{~kg}$ dengan nilai penerimaan Rp. 45.304.000,-

3. Nilai penerimaan kotor anggota kelompok tani bioindustri pada tahun 2019 sebesar Rp. 466.633.000- dengan rata-rata penerimaan setiap kelompok sebesar Rp. 155.544.333,-

4. Masih diperlukan peningkatan dan penguatan kinerja kelompok khususnya terhadap peningkatan kinerja anggota, pemanfaatan kelompok tani (gapoktan) sebagai pusat perencanaan dan pelaksanaan kerja anggota.

\section{DAFTAR PUSTAKA}

Adnyana, M.O. 2005. Pengembangan sistem integrasi tanaman-ternak bebas limbah di KP Muara. Pusat Penelitian dan Pengembangan Tanaman Pangan, Bogor.

Adnyana, M.O., A.K. Makarim, U.D.Djaenudin, I G.M. Subiksa, B. Haryanto,Marwan, dan R. Tjahjohutomo. 2007. Master Plan dan Business Plan Merauke Integrated Rice Estate (MIRE), Kabupaten Merauke, Papua.

APCC (Asian Pacific Coconut Community). 2007. Negeri Berjuta Cocos. Trubus 467 (Desember 2008/XXXIX): 32

Badan Penelitian dan pengembangan Pertanian, 2005. Prospek dan Arah Pengembangan Agribisnis Kelapa.

Badan Pusat Statistik Sulawesi Barat, 2019. Sulawesi Barat dalam Angka. Badan Pusat Statistik. Mamuju.

Badan Pusat Statistik Kabupaten Majene, 2019.

Diterbitkan Oleh, 
Majene Barat dalam Angka. Badan Pusat Statistik. Majene.

BALITKA, 2004. Pascapanen Kelapa. Monograf. Balai Penelitian Kelapa dan Palma Lain Manado, C.V. Kunci Berkat-Manado. 116 hal.

Brotosunaryo, O.A.S. 2003. Pemberdayaan petani kelapa. Prosiding Konfrensi Nasional Kelapa V. Tembilahan, 22-24 Oktober 2002. Hal 10-16

Dinas Perkebunan Provinsi Sulawesi Barat. 2013. Statistik Perkebunan. Pemerintah Provinsi Sulawesi Barat.

Dinas Perkebunan Provinsi Sulawesi Barat. 2013. Profil Potensi Pengolahan Hasil Komoditas Unggulan Perkebunan Provinsi Sulawesi Barat

Diwyanto, K. dan B. Haryanto. 1999. Pembangunan pertanian ramah lingkungan: Prospek pengembangan ternak pola integrasi (Suatu konsep pemikiran dan bahan diskusi). Pusat Penelitian dan Pengembangan Peternakan,Bogor.

Diwyanto, K. dan E. Handiwirawan. 2004. Peran Litbang dalam mendukung usaha agribisnis pola integrasi tanaman-ternak. Pros. Seminar Nasional Sistem Integrasi Tanaman-Ternak. Denpasar, 20 - 22 Juli 2004. Puslitbang Peternakan bekerjasama dengan BPTP dan CASREN. hlm. $63-80$.

Diwyanto, K. Bambang, RP. Dan Darwinsyah, L. 2001. Integrasi Tanaman Ternak Dalam Pengembangan Agribisnis Yang Berdaya Saing Berkelanjutan Dan Berkerakyatan. Disampaikan Pada Seminar Nasional teknologi Peternakan dan Veteriner. Puslitbangnak. Bogor.

Hamdani, M. 2008. Sistem Pertaninan Terpadu untuk peningkatan produktivitas lahan dan kesejahteraan petani. Makalah. Workshop Teknologi unutuk Masyarakat. Gedung KORPRI Serang-Banten, 24 Desember 008.
Irawan. B. 2006. Pelaksanaan PRA dan Rancang Bangun Agibisnis Materi disampaikan pada Workshop Prima Tani di Ciloto tanggal 19-22 September 2006. BBP2TP. Bogor.

Kariyasa, K. 2005. Sistem Integrasi TanamanTernak dalam perspektif reorientasi kebijakan subsidi pupuk dan peningkatan pendapatan petani. Analisis Kebiajkan Pangan. Vol 3 No. 1, Maret 2005. Pusat Penelitian dan Pengembangan Sosial Ekonomi Pertanian. Badan Litbang Pertanian. Jakarta.

Kusnadi, U. 2007. Inovasi Teknologi Peternakan Dalam Sistem Integrasi Tanaman dan Ternak (SITT) Untuk Menunjang Swasembada Daging Tahun 2010. Orasi pengukuhan profesor riset Badan Penelitian dan Pengembangan Pertanian.

Nitis, I.M. 1995. Research methodology for semiarid crop-animal systems in Indonesia. Crop-Animal Interaction. In C. Devendra and C. Sevilla (Eds.). IRRI. Discussion Paper Series No. 6. IRRI, Manila, Philippines

Makka,D. 2004. Prospek Pengembangan system integrasi peternakan yang berdaya saing. Pros. Seminar Nasional Sistem Integrasi Tanaman-Ternak. Dempasar, 20-22 Juli 2004. Puslitbang Peternakan bekerjasama dengan BPTP Bali dan CASREN.hlm.1831.

Pantjar Simatupang 2014. Pengembangan program bioindustri mendukung strategi induk pembangunan pertanian. |Informasi BBalitvet |Kamis, 06 Pebruari 2014)

Suswono 2014a. Sektor Pertanian Akan Menjadi Bio Industri Sabtu, 25 Januari 2014 16:32 wib | Dani Jumadil Akhir economy.Okezone.com

Suswono 2014 ${ }^{\text {b }}$. Menteri pertanian gagas bioindustri di pedesaan. Jakarta. kabarbisnis.com, Rabu (19/3/2014).

Diterbitkan Oleh, 